\title{
THE INSTITUTION OF ENVIRONMENTAL REPORTING IN JAPAN: AN EXPLORATORY STUDY
}

\author{
Afdal Madein \\ Hasanuddin University, Indonesia \\ E-mail: afdal@unhas.ac.id
}

\begin{abstract}
Although Japan has been having a high environmental reporting rate for a long time, the contextual factors promoting it are limitedly explored. Investigating them could enrich references to understand the improvement of this practice. Therefore, this study aimed to explore the contextual factors promoting this practice in Japan based on the Institutional Theory by applying thematic analysis to several official documents from the Japanese government. The analysis discovered regulative, normative, and cognitive elements emanating from regulations and initiatives from the Government, Japanese society and companies, and overseas practices, which promote environmental reporting as a tatemae. The findings provide a basic understanding of institutional elements endorsing environmental reporting in Japan to feed future research and other countries in improving this practice.
\end{abstract}

Keywords: environmental reporting, institutional theory, Japan

ARTICLE INFO

\section{Article History:}

Received: 5 June 2020

Accepted: 14 July 2020

Published: 31 December 2020 


\section{INTRODUCTION}

Based on the review of reports containing environmental, social, and governance information of the largest companies in many countries, the triennial surveys of KPMG (2002, 2005, 2008, 2011, 2013, 2015, 2017) show that Japan consistently has higher reporting rates than most of the countries since 2002. Kamath (2010), Ho and Taylor (2007), Kolk (2005), Schrader (2019), and WBCSD (2019) also found the impressiveness of Japanese companies in environmental reporting compared to companies from other advanced countries. The facts indicate that Japan, which is an Asian country, has been one of the countries having advanced environmental reporting practices in the world for a long time.

Many prior studies have examined factors improving this practice empirically and found the effect of internal and external or contextual pressures on this practice (e.g. Amran \& Haniffa, 2011; de Villiers \& Alexander, 2014; Laine, 2009; Contrafatto, 2014; Comyns, 2016; Frost, 2007; Fallan \& Fallan, 2009; Aerts, Cormier, \& Magnan, 2006; Bebbington, Kirk, \& Larrinaga, 2012). However, Mata, Fialho, and Eugénio (2018), who reviewed papers in leading accounting journals, show that there are only a limited number of articles analysing environmental reporting in Japan compared with Anglo-Saxon countries, such as the US, the UK, and Australia. They also suggest that highlighting the organisational field of companies in less-explored geographical areas could uncover other situations in this practice. Moreover, it is widely known that Japan is different from the US and European countries in which its environmental policies have relied more on a voluntary approach (Arimura, Kaneko, Managi, Shinkuma, Yamamoto, \& Yoshida, 2019). Therefore, this study aimed to identify contextual factors promoting corporate environmental reporting to uncover unique factors in Japan.

The data collection and analysis used the Institutional Theory for conducting a thematic analysis on several official documents and interpreting the findings. The results show that regulative, normative, and cognitive pressures emanating from regulations and initiatives from the Government, Japanese society and companies, and overseas practices are contextual factors promoting this practice through coercive, normative, and mimetic isomorphism. Further analysis showed that those elements substantively 
require environmental reporting but promotes it as a tatemae, which could destroy harmony in the society if it is not followed (Doi, 1986; Wagatsuma \& Rosett, 1983). This is relevant for companies in Japan, which are much more significant to pursue self-regulation (jishukisei) than companies in other countries (Schaede, 1999). Overall, the findings contribute by enriching references to understand efforts promoting environmental reporting for future research and for other countries to improve this practice.

The remainder of this paper is structured as follows. The next section reviews the literature and environmental reporting in Japan. It is followed by the theoretical framework, the research method, the findings, the discussions, the conclusions and, finally, the limitations and future research.

\section{LITERATURE REVIEW}

In the late 1980s, Japanese companies provided less information on topics related to the environment (Yamagami \& Tomimasu, 1993; Yamagami \& Kokubu, 1991). Iwata, Arimura, and Takenouchi (2008) report that the early advancement of environmental reporting in Japan began in the late 1990s. They discovered an increasing trend by 1.4 times, 1.5 times, and 1.9 times in 1997, 1998, and 1999, respectively, compared to the previous year. To date, the proportions of Japanese companies disclosing environmental information in the triennial surveys of $\operatorname{KPMG}(2002,2005,2008,2011$, 2013, 2015, 2017) imply that Japan has institutionalised the environmental reporting practice.

Prior research in other countries have found that the progress of environmental reporting is driven by internal and external or contextual pressures of the companies. Studies focused on contextual factors found institutional factors (Amran \& Haniffa, 2011; de Villiers \& Alexander, 2014; Laine, 2009; Contrafatto, 2014), specifically environment-related regulations (Comyns, 2016; Frost, 2007; Fallan \& Fallan, 2009), other firm practices (Aerts et al., 2006), and reporting norms (Bebbington et al., 2012) as essential factors improving this practice. Other studies highlight the role of the characteristics of countries of origin (Buhr \& Freedman, 2001; Chapple \& Moon, 2005; Fifka \& Drabble, 2012; Holland \& Foo, 2003; Smith, Adhikari, \& Tondkar, 2005; Wanderley, Lucian, Farache, \& De Sousa Filho, 2008; Freedman \& Jaggi, 2005). 
However, based on a literature review, this study found only limited studies focused on factors improving environmental reporting in Japan. They are Kokubu, Noda, Onishi, and Shinabe (2001); Burritt, Christ, and Omori (2016); Yook, Song, Patten, and Kim (2017); Gnanaweera and Kunori (2018); and Ho and Taylor (2007), who focussed more on the effect of internal pressures or firm characteristics. Ho and Taylor (2007) indeed covered contextual factors, but they focussed on comparing the Japanese and US contexts in several terms. Two other studies showing contextual factors are Kokubu, Nashioka, Saio, and Imai (2003), who examined the preference of companies on guidelines published by two ministries in Japan, and Saka and Burritt (2003), who explained several factors promoting this practice in a limited way. Kawahara (2017), who reviewed Japanese literature, found only Komura (2009) focusing on institutional factors for improving sustainability reporting. Komura conducted interviews on three companies and found the effect of pressures from other companies and overseas trends on sustainability reporting. To conclude this section, Japan has an established environmental reporting practice, but previous studies have only limitedly explored the contextual factors promoting it.

\section{THEORETICAL FRAMEWORK}

The Institutional theory is one of the most widely used theories in the environmental reporting field (Mata et al., 2018). Higgins, Milne, and van Gramberg (2015) urged its use it to find unique contexts in this field. The Institutional theory has variants in various fields (Scott, 1995), but its new sociology variant has probably had the most influence on accounting research (Moll, Burns, \& Major, 2006).

This theory originates from the interpretive paradigm, but later it was also developed using the positivist paradigm (Bowring, 2000). Also, there are several new versions of it called institutional work (Lawrence, Suddaby, \& Leca, 2011) and institutional entrepreneurship (Leca \& Naccache, 2006), which focus more on the practice of actors in changing the institution, and institutional logic, which focuses on heterogeneity of cultural meaning and how it comparatively varies by institutional order (Thornton, Ocasio, \& Lounsbury, 2015). However, they did not fit whit the aim of this study. Several recent studies have also continued to utilise this Institutional Theory 
and also used it in the positivist approach such as Comyns (2016, 2018); Chelli, Durocher, and Richard (2014); de Villiers and Alexander (2014); and Aerts et al. (2006).

This theory assumes that organisational structures and behaviours are mostly influenced by contextual factors rather than internal economic objectives (Moll et al., 2006). It overlooks economic rationality (Meyer \& Rowan, 1977) and focuses on the structural determinants that organisations perceive as rational or prudent (Dimaggio \& Powell, 1983). The main concept of this theory suggests that institutions affect organisational structures and behaviours (Meyer \& Rowan, 1977) in a specific organisational field (Dimaggio \& Powell, 1983). Specifically, organisational practices will reflect rules, ideas, and norms that are generally accepted within organisational fields (Moll et al., 2006), including corporate practices on environmental reporting.

Gray, Owen, and Adams (2009) argue that this theory is most typically associated with Dimaggio and Powell (1983) and Scott (1995). Scott defines institutions as consisting of cognitive, normative, and regulative structures and activities that govern organisational behaviours. Scott also explains that (1) regulative element involves the capacity to establish rules, inspect or review others' conformity to them, and as necessary, manipulate sanctions rewards or punishments in an attempt to influence future behaviour (1995, p. 35); (2) normative element includes both values and norms (1995, p. 37); and (3) cognitive elements consists of rules that constitute the nature of reality and the frames through which meaning is made (1995, p. 40). Meanwhile, Dimaggio and Powell (1983) explain the homogeneity of organisational practices and use isomorphism as the concept to captures the process of homogenization. They introduced three mechanisms through which institutional-isomorphic change occurs with its antecedents: (1) coercive isomorphism that stems from political influence and problem of legitimacy; (2) mimetic isomorphism resulting from standard responses to uncertainty; and (3) normative isomorphism, associated with professionalization (1983, p. 150).

The two works are interconnected in which Scott's (1995) elements of institutions shape the behaviours of organisations through processes similar to Dimaggio and Powell's (1983) isomorphic mechanisms. Therefore, this 
study used them as a framework for collecting and interpreting the data, as explained in the next section. This approach is similar to what Laine (2009) did on issues addressed in environmental reports, and Contrafatto (2014) performed on subjects discussed in interviews.

\section{RESEARCH METHOD}

The method was an exploratory qualitative research focused on official documents to find regulative, normative, and cognitive pressures advancing environmental reporting in Japan. This study collected laws related to environmental reporting from 1967 to 2017 to discover regulative elements. The laws are available in the Japanese Law Translation Database System of the Ministry of Justice except Act No. 77 of 2004, which is provided by the Ministry of Environment (MOE) on its website. This research also collected other official documents published by the Japanese government to investigate normative and cognitive structures, which are covert. They were the English translation version of the Environmental Reporting Guideline published by MOE in 2000, 2003, 2007, and 2012, and the Environmental Reporting Guideline issued by the Ministry of Economy, Trade, and Industry (METI) in 2001, especially their introduction part. Another set of documents was the Eco-Friendly Corporate Behaviour Survey (Eco Survey), which was published by MOE from 1998 to 2015 in Japanese, especially their environmental reporting section. This study assumed that the documents recorded the contextual factors promoting environmental reporting in Japan because they discussed growing issues regarding this practice. 


\section{Table 1: Examples of Several Elements of the Institution Identified and Their Sources}

\begin{tabular}{|c|c|c|c|c|}
\hline \multirow{2}{*}{ Documents } & \multirow{2}{*}{ Statements } & \multicolumn{3}{|c|}{ Themes } \\
\hline & & Regulative & Normative & Cognitive \\
\hline $\begin{array}{l}\text { Act No. } 77 \text { of } \\
2004\end{array}$ & $\begin{array}{l}\text { "Article } 9(1) \text { : Specified } \\
\text { Corporations ... must prepare } \\
\text { and publish an environmental } \\
\text { report for each business or } \\
\text { financial year... Article } 16: \text { A civil } \\
\text { fine of up to } 200,000 \text { yen shall be } \\
\text { imposed on executive officer(s) if } \\
\text { a Specified Corporation fails to } \\
\text { publish an environmental report } \\
\ldots \text { or publishes a false report." }\end{array}$ & Direct law & & \\
\hline $\begin{array}{l}\text { Act No. } 117 \\
\text { of } 1998\end{array}$ & $\begin{array}{l}\text { "Parties ... producing } \\
\text { considerably high greenhouse } \\
\text { gas emissions in ... their } \\
\text { business activities... shall report } \\
\text { every fiscal year, .... to the } \\
\text { minister who has jurisdiction over } \\
\text { the area of business ... on the } \\
\text { matters ... concerning the carbon } \\
\text { dioxide equivalent greenhouse } \\
\text { gas emissions produced during } \\
\text { a period..." }\end{array}$ & & Indirect laws & \\
\hline $\begin{array}{l}\text { Environmental } \\
\text { Reporting } \\
\text { Guideline } \\
2000\end{array}$ & $\begin{array}{l}\text { "...when citizens make a decision } \\
\text { to act on their environmental } \\
\text { consciousness, it is necessary } \\
\text { to know organizations' significant } \\
\text { information a bout their } \\
\text { environmental efforts. Citizens } \\
\text { are seeking environmental } \\
\text { information. The importance is } \\
\text { widely recognized to fulfill the } \\
\text { needs of citizens by providing } \\
\text { and reporting environmental } \\
\text { information." }\end{array}$ & & $\begin{array}{l}\text { Environmental } \\
\text { awareness of } \\
\text { society }\end{array}$ & \\
\hline $\begin{array}{l}\text { Environmental } \\
\text { Reporting } \\
\text { Guideline } \\
2000\end{array}$ & $\begin{array}{l}\text { "Accordingly, the Ministry of } \\
\text { the Environment have revised } \\
\text { the } 1997 \text { guideline, in order to } \\
\text { encourage the publication of } \\
\text { environmental reporting of higher } \\
\text { quality." }\end{array}$ & & $\begin{array}{l}\text { Environmental } \\
\text { r e p o r t i n g } \\
\text { guidelines }\end{array}$ & \\
\hline $\begin{array}{l}\text { Environmental } \\
\text { Reporting } \\
\text { Guideline } \\
2001\end{array}$ & $\begin{array}{l}\text { "As environmental consciousness } \\
\text { in entities activities has risen in } \\
\text { recent years, the importance of } \\
\text { environmental communication } \\
\text { and social accountability... has } \\
\text { been widely recognized." }\end{array}$ & & $\begin{array}{l}\text { Environmental } \\
\text { awareness of } \\
\text { companies }\end{array}$ & \\
\hline
\end{tabular}




\begin{tabular}{|c|c|c|c|c|}
\hline \multirow{2}{*}{ Documents } & \multirow{2}{*}{ Statements } & \multicolumn{3}{|c|}{ Themes } \\
\hline & & Regulative & Normative & Cognitive \\
\hline $\begin{array}{l}\text { Eco-Friendly } \\
\text { Corporate } \\
\text { Behaviour } \\
\text { Survey } 2000\end{array}$ & $\begin{array}{l}\text { What is the purpose of } \\
\text { your company to disclose } \\
\text { environmental information? } \\
\ldots \text { To publish environmental } \\
\text { information in accordance with } \\
\text { information disclosure systems } \\
\text { in Europe and the United States } \\
(3.5 \%) \text { " }\end{array}$ & & & $\begin{array}{l}\text { Overseas } \\
\text { operations }\end{array}$ \\
\hline $\begin{array}{l}\text { Eco-Friendly } \\
\text { Corporate } \\
\text { Behaviour } \\
\text { Survey } 2015\end{array}$ & $\begin{array}{l}\text { What are the guidelines, etc. that } \\
\text { you referred to when preparing } \\
\text { the environmental report? ... } \\
\text { Other environmental report } \\
(33 \%)\end{array}$ & & & $\begin{array}{l}\text { Le ading } \\
\text { companies }\end{array}$ \\
\hline
\end{tabular}

The approach to analysing themes of information in documents is thematic analysis. It follows what Boyatzis (1998) defines as a theoreticaldriven approach or Crabtree and Miller (1999) call as a template of codes approach. The first step was deductively generating themes using Scott's (1995) elements of institutions. The next was to identify regulations, initiatives, organisations, events, and ideas related to environmental reporting in the documents based on the theme templates. The results were several elements that provided regulative, normative, and cognitive pressures on environmental reporting. Table 1 shows examples of several elements identified and their sources.

Based on the elements identified, this study collected and analysed several additional essential documents. The purposes were to find further information about those elements and to confirm them using other data. They were documents related to the Network for Environmental Reporting, the Keidanren's Voluntary Action Plan on the Environment, the Environmental Brand Survey, the Environmental Communication Award, and the Environmental Reporting Award. The other documents are the environmental reports of Sony Corporation, Matsushita Electric (currently known as Panasonic Corporation), and Fujitsu, which were the winners of the two awards in the early periods. Finally, this study interpreted those elements based on Dimaggio and Powell's (1983) institutional mechanism to show how those elements have enhanced environmental reporting in Japan. 


\section{FINDINGS}

Table 2 shows the institutional elements that provided regulative, normative, and cognitive pressures to improve environmental reporting in Japan extracted from several official documents through a thematic analysis.

Table 2: The Elements of the Institution of Environmental Reporting Practice in Japan

\begin{tabular}{|c|c|c|}
\hline $\begin{array}{c}\text { Regulative } \\
\text { Element }\end{array}$ & Normative Element & $\begin{array}{l}\text { Cognitive } \\
\text { Element }\end{array}$ \\
\hline $\begin{array}{l}\text { Act No. } 77 \\
\text { of } 2004\end{array}$ & $\begin{array}{l}\text { - Indirect laws } \\
\circ \text { Act No. } 117 \text { of } 1998 \\
\circ \text { Act No. } 49 \text { of } 1979 \\
\circ \text { Act No. } 86 \text { of } 1999 \\
\circ \text { Act No. } 137 \text { of } 1970 \\
\text { - Environmental accounting and reporting } \\
\text { guidelines } \\
\text { - Environmental awareness of society } \\
\circ \text { Environmental reporting awards } \\
\circ \text { Environmental ratings } \\
\circ \text { Network for Environmental Reporting } \\
\text { - Environmental awareness of companies } \\
\circ \text { Keidanren } \\
\circ \text { EMS certification }\end{array}$ & $\begin{array}{l}\text { Overseas } \\
\text { operations } \\
\text { - Leading } \\
\text { companies }\end{array}$ \\
\hline
\end{tabular}

\section{Laws Related to Environmental Reporting}

The Act on the Promotion of Business Activities with Environmental Consideration (Act No. 77 of 2004) was enacted in 2004 and enforced in 2005. Article 9 of it requires specific corporations to publish an environmental report and imposes a sanction on their executive officers if they fail to issue an environmental report. The specific corporations are corporations established under a particular law and governed by the ordinance, for example, national universities and independent administrative agencies. The law, in article 11, also encourages common large corporations to disclose an environmental report but without a specific sanction for corporations that do not publish it. The law also suggests that corporations should enhance the reliability of their environmental report. Correspondingly, for the first time, Matsushita Electric provided a third-party assurance for its 
environmental report in 2006, one year after the effective date of this law, whereas Fujitsu and Sony Corporation have had such assurance since 2000 and 2001, respectively.

Four other laws are laws indirectly related to environmental reporting. They are Act on Promotion of Global Warming Countermeasures (Act No. 117 of 1998), the Pollutant Release and Transfer Register (PRTR) law of Japan (Act No. 86 of 1999), and Act on the Rational Use of Energy (Act No. 49 of 1979), and Act on Waste Management and Public Cleansing (Act No. 137 of 1970). The first has mandated certain companies to report their greenhouse gas emissions to the authorities since 2006, while the second has necessitated particular companies to track and report their chemical substances released and transferred during the preceding fiscal year to the authorities. Also, the third has required other specific companies to report their energy consumption to the authorities since 1993. The latter demands companies emitting a large quantity of wastes to report the status of their waste management. Although the laws require companies to submit only to the authorities, the public environmental reporting of Sony Corporation, Panasonic Corporation, and Fujitsu commonly also disclosed identical information with the information required by the laws.

\section{Environmental Accounting and Reporting Guidelines}

In 1992 and 1995, METI (formerly known as Ministry of International Trade and Industry) published a Voluntary Plan, which was a guideline mentioning the disclosure of environmental information. In the guideline, Japanese companies were requested to disclose specific environmental information even though it was not intended as a guideline for environmental reporting. Finally, the Environment Agency (the former of MOE) provided the Environmental Reporting Guideline in 1997 and the Environmental Accounting Guideline in 1999.

MOE and METI continue to improve environmental reporting in Japan by providing many reporting guidelines related to environmental issues. Japanese companies generally combine them in preparing environmental reports. However, the two series of Eco Survey conducted by MOE in 2014 and 2015 show that the Environmental Reporting Guideline provided by MOE is the most used guideline. They also report that many Japanese companies use the GRI Sustainability Reporting Guideline. 


\section{Environmental Awareness of Japanese Society}

The perseverance of Japanese society to deal with the daily complicated garbage disposal system represents that they are aware of environmental issues. Moreover, they need corporate environmental information, as one of the documents analysed (Environmental Reporting Guideline 2000) states that "Local public..., in some cases, need environmental information on businesses, since there is the potential for suffering problems in prompting environmental conservation." Correspondingly, Japanese companies react to this concern, as the Corporate Senior Executive Vice President of Fujitsu in the Fujitsu Group Sustainability Report 2006 states that

"...we acknowledge that our disclosure of information concerning certain soil and groundwater contamination surveys that we have conducted has been inadequate, and this has given rise to much concern among local residents. We are taking this issue seriously, have created new company internal rules, and are reviewing our approach to information disclosure."

This study also found three initiatives discussed in the guideline documents, which represent the awareness of Japanese society on environmental reporting. They are environmental ratings, environmental reporting awards, Network for Environmental Reporting (NER). Japanese society involved in initiating these initiatives.

\section{Environmental reporting awards}

There are two popular environmental reporting awards in Japan. One is the Environmental Communication Award, which was established in 1997 and is co-sponsored by the Global Environmental Forum and MOE. The second is the Environmental Reporting Award, which was started in 1998 and is joint-hosted by Toyo-Keizai Inc. and Green Reporting Forum. Their purpose is to improve the quality of environmental reporting. In several times, the Environmental Communication Award increased its award criteria. For example, it has given more points to reports which provide negative environmental information and information related to economic impacts of environmental management, including environmental accounting, since 2013, and which provide information related to biodiversity 
since 2009. Also, it has introduced special awards for environmental financial reports and biodiversity reports since 2009 .

\section{Environmental ratings}

One of the documents reviewed in this study discussed the global improvement of environmental ratings in Europe, which were started to rate more Japanese companies. It also mentioned the cases in which private research institutes, universities, and newspapers surveyed environmental conservation efforts of companies and published the results. One of the pioneers of environmental ratings in Japan is the Nikkei Business Publications, which launched the Environmental Brand Survey in 2000. It rates Japanese companies based on the quality of their environmental communication. It has started to give points on the environmental report of companies to determine their ratings since 2004.

\section{Network for Environmental Reporting (NER)}

NER was established by companies, organisations, universities, and citizens that were interested in environmental reporting in 1998. This study found its formation documents in MOE's website, which implied that this network was established by Japanese society but also backed up by the Government. The initial members were 30 environmental report providers from companies, company federations, and administrative districts and 27 recipients from non-governmental organisations and academic experts. The aims were to promote and to develop environmental communications through environmental reports. This network conducted research collaborating with various stakeholders and disseminated information widely to improve the quality of the environmental report. Members sought to formulate partnerships to prepare and publish environmental reports or to become recipients of environmental reports. At its inception, some of the members were the winners of the two popular reporting awards.

\section{Environmental Awareness of Japanese Companies}

Several documents reviewed in this study discussed the Japanese business concern over environmental issues. Moreover, this study found that this concern had affected the importance of voluntary environmental 
disclosures, as one of the documents (Environmental Reporting Guideline 2001) stated that "As environmental consciousness in entities activities has risen in recent years, the importance of environmental communication and social accountability... has been widely recognized."

To explore more clearly the correlation between environmental concern and environmental reporting, this study focussed on the Keidanren's Voluntary Action Plan on the Environment as a representation of business concern on environmental issues. Another event discussed in the guideline documents and correlating to environmental concern is the environmental management system certifications.

\section{Keidanren}

Keidanren (Japan Federation of Economic Organisations) was established in August 1946. It is a powerful and influential business association in Japan. Keidanren has a Charter of Corporate Behaviour, which had been revised six times from 1991 to 2017. The revisions showed an increase of concern over environmental issues.

Keidanren established a Voluntary Action Plan on the Environment in 1997 to encourage industries to deal with environmental challenges more concretely. There were 37 industry groups drafted plans in cooperation with 137 industrial organisations. Some industries stated clearly their plan to disseminate their environmental information such as Limestone Mining Industry, Housing, Chemical, and Real Estate. This plan ended in 2012, but another plan was initiated in 2013, namely the Commitment to a Low Carbon Society.

Keidanren evaluated the plan and published evaluation reports covering information about the environmental performance of industries (not individual firms) every year. METI also released this information annually. Regarding individual environmental reports, Keidanren published survey results in 2005, 2006, and 2007 showing that $62 \%-66 \%$ from $480-570$ of responding members had already issued environmental reports. 


\section{Environmental management system (EMS) certification}

Japanese companies commonly pursue certification on their EMS, which correlated with their environmental reporting practice. The content of their environmental disclosures usually discussed EMS certification. For example, the executives of Sony Corporation, Fujitsu, and Matsushita Electric address the ISO 14001 certification in their message on issuing environmental information in many years. Moreover, Matsushita Electric disclosed environmental performance data only for its sites which has ISO 14001 certification. Also, Matsushita Electric used at least $11 \%$ of their environmental report pages to disclose their ISO 14001 information in 2000.

To date, the number of Japanese companies and sites having ISO 14001 certification is one of the most in the world (ISO, 2017). Japan also has EcoAction 21, which is a local EMS certification program. It is similar to ISO 14001 but mainly for small and medium-sized organisations.

\section{Overseas Operations}

Other countries have influenced Japanese companies in environmental reporting. The Eco Survey from 1998 to 2003 documents that one of the purposes of Japanese companies in publishing environmental reports was to follow other countries. More specifically, the surveys showed that 2.2-3.6\% of sample companies published environmental reports to follow disclosure systems of other countries such as the European Union (EU) and the US.

European countries and the US, which were important markets of Japanese companies in the late 1990s, have practised environmental reporting. They have had regulations and initiatives to encourage their companies to disclose environmental reports before the emergence of this practice in Japan. The US has required its companies to disclose environmental information since before the 1990s through the Securities and Exchange Commission (SEC) and the Toxic Release Inventory (TRI) (GAO, 2004). Meanwhile, the EU has promoted the provision of information about environmental performance to the public through the Eco-Management and Audit Scheme (EMAS) since 1993 (EU 1993). Both the EU and the US did not require Japanese companies to disclose environmental reports. 
However, environmental reporting practices had already been prevalent earlier in these areas than in Japan.

\section{Leading Companies}

Japanese companies followed the reporting practices of other companies in preparing their environmental report. The two series of Eco Survey in 2014 and 2015, 39\% and 33\% of the sample respectively used environmental reports of other companies as a reference in preparing their environmental reports. Correspondingly, the two environmental reporting awards mentioned above routinely selected companies that have great environmental reports. In addition, in the early advancement of environmental reporting practices, those two programs consistently chose Fujitsu, IBM Japan, Kirin Brewery, Matsushita Electric, and Sony Corporation as companies performing well in environmental reporting, as shown in Table 3.

Table 3: The Performance of the Leading Companies in the Environmental Communication Award (ECA) and Environmental Reporting Award (ERA)

\begin{tabular}{lccccccc}
\hline \multirow{2}{*}{ Companies } & 1997 & \multicolumn{2}{c}{1998} & \multicolumn{2}{c}{1999} & \multicolumn{2}{c}{2000} \\
\cline { 2 - 8 } & ECA & ERA & ECA & ERA & ECA & ERA & ECA \\
\hline IBM Japan, & & $1^{\text {st }}$ & $1^{\text {st }}$ & $2^{\text {nd }}$ & & $3^{\text {rd }}$ & \\
\hline Sony Corporation & $1^{\text {st }}$ & $2^{\text {nd }}$ & & & $1^{\text {st }}$ & $2^{\text {nd }}$ & \\
\hline Kirin Brewery & $1^{\text {st }}$ & $2^{\text {nd }}$ & & $3^{\text {nd }}$ & $1^{\text {st }}$ & $3^{\text {rd }}$ & $2^{\text {nd }}$ \\
\hline Matsushita Electric & $1^{\text {st }}$ & & & $3^{\text {rd }}$ & $1^{\text {st }}$ & $3^{\text {rd }}$ & $1^{\text {st }}$ \\
\hline Fujitsu & & $3^{\text {rd }}$ & $3^{\text {rd }}$ & $3^{\text {rd }}$ & $2^{\text {nd }}$ & $3^{\text {rd }}$ & \\
\hline
\end{tabular}

Their environmental reports had superiority in content and data presentation. They pioneered methods in environmental reporting, including how to present environmental data, types of information to be provided, and scopes of environmental reports. IBM Japan was the pioneer in disclosing environmental financial information, and Fujitsu was the forerunner in obtaining third-party certification of environmental accounting data and providing a further environmental accounting guideline. Sony Corporation was excellent in determining the scope of reports. In visualising environmental data, Matsushita Electric and Kirin Brewery were superior especially in using graphics. 


\section{DISCUSSIONS}

This part discusses the findings based on Dimaggio and Powell's (1983) isomorphic mechanisms to interpret how the elements identified promoted corporate environmental reporting in Japan. Table 4 shows the coincidence of the improvement of environmental reporting in Japan and the introduction date of the elements identified. Panel A shows that the survey of MOE and Iwata et al. (2008), both using a different method, showed that the early advancement of environmental reporting in Japan began in the late 1990s until around 2005. Concurrently, most of the elements of the institution identified were introduced around the late 1990s until the early 2000s, as shown in Panel B.

Furthermore, the survey of MOE from 1998 until 2015 also showed that Japanese companies consistently chose "to fulfil social responsibility" as their top purpose in providing environmental information rather than several economic-driven rational choices such as "to communicate with stakeholders," "to promote their environmental conservation effort," and "to educate their employees." It justifies the role of non-economic driven pressures on corporate environmental reporting practices in Japan. Therefore, it is reasonable to explain the improvement of environmental reporting in Japan using the three elements and mechanisms of the Institutional Theory. 
Table 4: The Coincidence of the Improvement of Companies

Publishing Environmental Reports and The Introduction of Several Elements of the Institution Identified in This Study

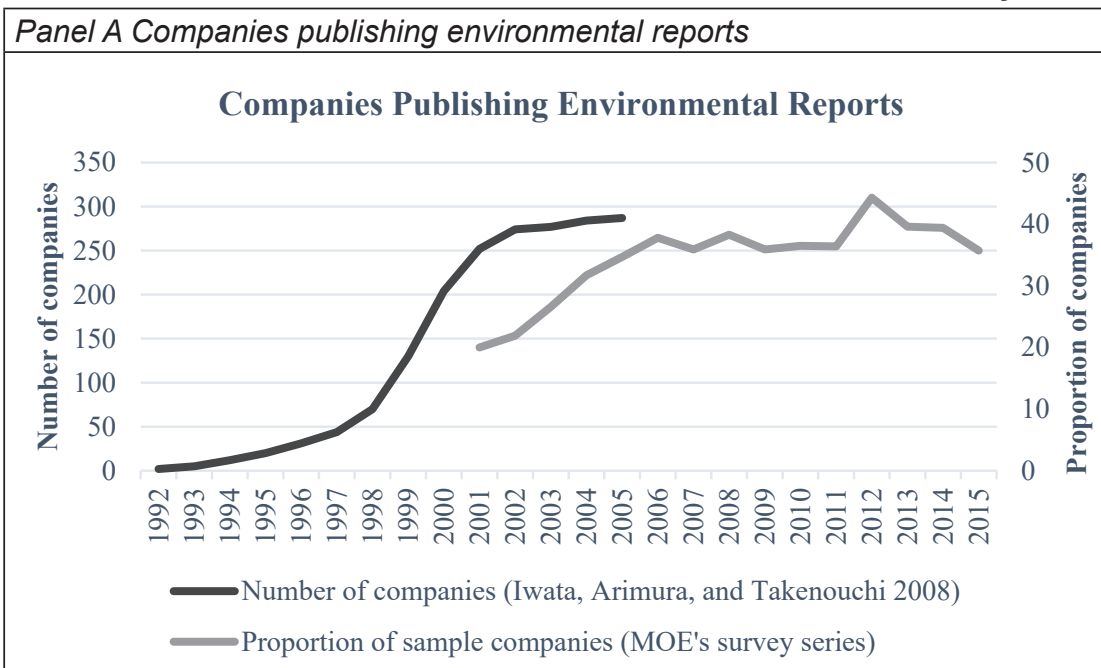

Panel B The introduction date of the elements

- Before 1996: IBM Japan, Kirin Brewery, and Sony Corporation published their first environmental report; The EU and US have had regulation related to environmental reporting; The enactment of Act on the Rational Use of Energy.

- 1996-2000: Fujitsu and Matsushita Electric published their first environmental report; The enactment of the Pollutant Release and Transfer Register (PRTR) law of Japan; The first edition of the environmental reporting guideline, environmental accounting guideline, and environmental reporting awards; The establishment of Network for the Environmental Reporting and Keidanren's Voluntary Action Plan on the Environment; The first introduction of ISO 14001.

- 2001-2005: The enactment of Act on the Promotion of Business Activities with Environmental Consideration; The Environmental Brand Survey has started to include the environmental report in its rating evaluation.

- After 2005: Act on Promotion of Global Warming Countermeasures has required certain companies to report their greenhouse gas emissions to the authority

\section{Regulative Element and Coercive Mechanism}

Based on Scott's (1995) idea, Act No. 77 of 2004 provides a regulative element to the organisational field of Japanese companies. It sets a rule with an economic punishment for those specific corporations if they fail to issue an environmental report or publish a false report. This creates formal pressure for those corporations and applies coercion to affect their 
behaviour (Dimaggio \& Powell, 1983) to publish environmental reports. Correspondingly, several studies on other countries have also found that direct regulations increased the number of companies reporting and the level of information disclosed, such as Frost (2007) in Australia, Fallan and Fallan (2009) in Norway, Chelli et al. (2014) in France, and Criado-Jiménez, Fernández-Chulián, and Husillos-Carqués (2008) in Spain.

\section{Normative Element and Normative Mechanism}

Normative elements include values, which mean conceptions of the preferred or desirable behaviours (Scott, 1995). The four indirect laws represent the desire of the Japanese government to see companies disclosing environmental information by requiring them to submit performance on greenhouse gas emission, chemical substances released and transferred, and energy consumption. Similarly, Japanese society prefers to see companies publishing environmental performance by establishing several initiatives to define and to reward good quality environmental reports. Also, the involvement of Japanese companies in the Keidanren's Voluntary Action Plan and pursuing EMS certifications has led them to prefer to disclose environmental information. These preferred or desirable behaviours of the Government, society, and companies are underlying values, which facilitate the advancement of environmental reporting (Bebbington et al., 2012).

Normative elements also consist of norms that determine how things should be done (Scott, 1995). Environmental accounting and reporting guidelines, environmental ratings and reporting awards, and the Network for Environmental Reporting represent these norms. The guidelines show how Japanese companies should disclose environmental information, and the network was similar to the ACCA's forum for formulating good quality environmental reporting practices in the UK (Bebbington et al., 2012). The ratings and reporting awards also work to create norms by rewarding Japanese companies based on their criteria.

Taking them together, they affect environmental reporting in Japan similarly to the work of two aspects of professionalisation in Dimaggio and Powell (1983). The first is the ability to produce cognitive bases; the second is the role as vehicles for spreading norms rapidly. The indirect laws, the guidelines, and the EMS certifications generate a cognitive base on how 
companies should disclose environmental information. The ratings and the network spread the best way to disclose environmental information rapidly. Meanwhile, the reporting awards and Keidanren work similarly with both of the two aspects by generating ideas about environmental reporting and disseminating them through the members or participants. Concurrently, previous research has shown the role of normative elements in advancing environmental reporting through normative mechanisms such as Comyns (2016) in EU companies, Amran and Haniffa (2011) in Malaysia, and de Villiers and Alexander (2014) in Australia and South Africa.

\section{Cognitive Element and Mimetic Mechanism}

As Act No. 77 of 2004 requires only those specific corporations and environmental reporting guidelines from the Government are only referred voluntarily, it is likely to produce uncertainty of purposes and approaches to this practice. Dimaggio and Powell (1983) explain that, as a standard response, companies will model themselves on other organisations to deal with this uncertainty. However, it is difficult to identify this cognitive structure (Higgins \& Larrinaga, 2014). Fortunately, the series of Eco Survey above detects some signals of mimetic isomorphism and indicates two sources of cognitive elements, namely overseas operations and other companies, which are also in line with Komura (2009).

Doing business abroad, such as in the EU or the US, provides opportunities to interact with other organisations, which show approaches to deal with this uncertainty. In these areas, environmental reporting had already been prevalent earlier than in Japan. It enables the cognitive element of the institution to create categories and to construct typifications, which lead Japanese companies to regard this practice as a specific practice (Scott, 1995) to deal with the uncertainty. Also, based on Dimaggio and Powell's (1983) idea, Japanese companies have inspirations on how to deal with environmental disclosure in their country through environmental reporting awards. The two reporting awards "have created models" by consistently rating specific companies as companies performing well in environmental reporting. The award programs also highlight the superior features of their reports. Correspondingly, Aerts et al. (2006) have shown mimetic processes in voluntary environmental reporting practices in Canada, France, and Germany empirically. 


\section{Environmental Reporting as Tatemae}

Up to this point, this study did not find any formal regulation requiring Japanese companies to publish an environmental report, except the requirement for those specific corporations mentioned above. On the other hand, Table 4 above implies that the improvement of environmental reporting practices is not experienced only by those specific corporations. Therefore, this improvement did not originate from formal requirements from the Japanese government.

Corresponding to this fact, Aoki (2000), Haley (1991), and Kagan (2000) inform that Japan is a country that tends to avoid formal regulations in governing companies. In the case of using formal regulations, Haley (1991, p. 186) claims that the law functions as tatemae in establishing the legitimate norms of principle that demark both ideals and boundaries. Orito and Murata (2008) also admit this claim.

Tatemae is any rule of conduct that the Japanese accept by unanimous agreement (Doi 1973), which is not different from the institution in which both are established based on consensus (Doi, 1986, p. 50). Tatemae also can be the expression of one's commitment or compliance with the demands of social norms (Wagatsuma \& Rosett, 1983). Logically, it is corresponding with the normative element of the institution in the Institutional Theory. Doi (1986, p. 36) show examples of the usage of this word, "The system requiring all students to live in the dormitories is the tatemae at this school." "We uphold the tatemae of equality between the sexes." "It has been decided that, as the tatemae, Japan will not maintain war capabilities." Doi (p. 61) states that Japanese conduct human relations based on tatemae and its pair called honne, which is personal motives and opinions (p. 37), and, furthermore, both as a pair is a unique characteristic of Japanese society (p. 47). Sato, Matsuda, and Carducci's (2018) concern of this pair confirms that it is still the characteristic of the Japanese nowadays.

The Japanese adopt and accept tatemae as the means of continuing one's social life smoothly (Wagatsuma \& Rosett, 1983). Furthermore, Wagatsuma and Rosett explain that an individual often finds that he or she must sacrifice his or her honne because traditional Japanese social norms emphasize harmonious interpersonal relations and group solidarity. 
It implies that even the tatemae is incongruent with the main purpose of Japanese (companies), they would probably act based on it to keep the harmony.

Furthermore, Schaede (1999) also informs that companies in Japan are much more significant to pursue self-regulation (jishukisei) than companies in other countries. Self-regulation is an arrangement set by a specific group and applies formal and informal regulation to the group members (Porter \& Ronit, 2006; Schaede, 1999). Self-regulation also covers how individual firms voluntarily perform environmental activities in the absence of or anticipation of government standards (Volden \& Wiseman, 2012).

The prevalence of Japan to function law as tatemae justifies why the Japanese government, through Act No. 77 of 2004, requires only those specific corporations to publish environmental reports while only encourage other large companies. In other words, the act indicates the intention of the Government to create tatemae by signalling the need for large companies to publish environmental reports. Another indication of the creation of tatemae is that the Government has provided several environmental reporting guidelines that companies adopt voluntarily. The four other laws also help to clarify what information should be disclosed. The other indication is that the Government has been involved with Japanese society in establishing the Environmental Communication Award and NER, which were also correlated with the "creating of model" in environmental reporting. These active efforts of the Government in promoting environmental reporting as a tatemae in Japan is a coincidence with environmental reporting practices overseas. In addition, it is congruent with the environmental activities of Japanese companies based on the Keidanren's Voluntary Action Plan on the Environment and EMS certification practices of Japanese companies. Therefore, Japanese companies smoothly accept and adopt this reporting practice as a tatemae. Moreover, their significant effort to pursue selfregulation (Schaede, 1999) multiplies their response to this tatemae. As a result, Japan consistently has great proportions of companies disclosing environmental information in the triennial surveys of $\operatorname{KPMG}(2002,2005$, 2008, 2011, 2013, 2015, 2017). 


\section{CONCLUSIONS}

This study explored the elements of the institution of environmental reporting in Japan through several official documents by using the exploratory qualitative research approach with thematic analysis and the Institutional Theory. Based on Dimaggio and Powell (1983) and Scott (1995), the findings show that regulative, normative, and cognitive pressures emanating from laws related to environmental reporting, environmental accounting and reporting guidelines, environmental awareness of Japanese society and companies, overseas operations, and leading companies are contextual factors promoting this practice through coercive, normative, and mimetic isomorphism. Further the analysis shows that those elements promotes environmental reporting as tatemae, which could destroy harmony in the society if it is not followed (Doi, 1986; Wagatsuma \& Rosett, 1983).

This study has theoretical and practical contributions. The findings provide a basic understanding of institutional factors promoting environmental reporting in Japan, which are limitedly explored. They enrich findings of prior research and also provide several new variables to be examined, such as indirect laws, business federations, and specific forums as factors improving this practice. Other countries also could refer to the overall findings to improve this practice.

\section{LIMITATIONS AND FUTURE RESEARCH}

This study used data from several official documents, including environmental reporting guidelines. However, it did not cover the new guideline published in 2018, which was beyond the scope of this research. Also, it only reviewed the English translation of the laws and the guidelines, which could limit the institutional factors identified. In addition, the findings depend on the validity of statements in the documents analysed, which could have been prepared with certain aims in mind. Future research could empirically examine the influence of the institutional factors identified in this study on environmental reporting. Also, it could be fruitful to investigate other limitedly-explored geographical areas to uncover more situations promoting this practice. 


\section{REFERENCES}

Aerts, W., Cormier, D., \& Magnan, M. (2006). Intra-industry imitation in corporate environmental reporting: An international perspective. Journal of Accounting and Public Policy, 25(3), 299-331.

Amran, A., \& Haniffa, R. (2011). Evidence in development of sustainability reporting: A case of a developing country. Business Strategy and the Environment, 20(3), 141-156.

Aoki, K. (2000). Comparing Japanese and American industrial effluent control: A case study of the consequences of contrasting regulatory styles. Law \& Policy, 22(3\&4), 319-351.

Arimura, T. H., Kaneko, S., Managi, S., Shinkuma, T., Yamamoto, M., \& Yoshida, Y. (2019). Political economy of voluntary approaches: A lesson from environmental policies in Japan. Economic Analysis and Policy, 64, 41-53.

Bebbington, J., Kirk, E. A., \& Larrinaga, C. (2012). The production of normativity: A comparison of reporting regimes in Spain and the UK. Accounting, Organizations and Society, 37(2), 78-94.

Bowring, M. A. (2000). De/constructing theory: A look at the institutional theory that positivism built. Journal of Management Inquiry, 9(3), $258-270$.

Boyatzis, R. E. (1998). Transforming qualitative information: Thematic analysis and code development. London: Sage Publications.

Buhr, N., \& Freedman, M. (2001). Culture, institutional factors and differences in environmental disclosure between Canada and the United States. Critical Perspectives on Accounting, 12(3), 293-322.

Burritt, R. L., Christ, K. L., \& Omori, A. (2016). Drivers of corporate water-related disclosure: Evidence from Japan. Journal of Cleaner Production, 129, 65-74. 
Chapple, W., \& Moon, J. (2005). Corporate Social Responsibility (CSR) in Asia: A seven-country study of CSR web site reporting. Business and Society, 44(4), 415-441.

Chelli, M., Durocher, S., \& Richard, J. (2014). France's new economic regulations: Insights from institutional legitimacy theory. Accounting, Auditing \& Accountability Journal, 27(2), 283-316.

Comyns, B. (2016). Determinants of GHG reporting: An analysis of global oil and gas companies. Journal of Business Ethics, 136(2), 349-369.

Comyns, B. (2018). Climate change reporting and multinational companies: Insights from institutional theory and international business. Accounting Forum, 42(1), 65-77.

Contrafatto, M. (2014). The institutionalization of social and environmental reporting: An Italian narrative. Accounting, Organizations and Society, 39(6), 414-432.

Crabtree, B. F., \& Miller, W. L. (1999). Using codes and code manuals: A template organizing style of interpretation. In B. F. Crabtree \& W. L. Miller (Ed.), Doing qualitative research (2 ${ }^{\text {nd }}$ ed., pp. 163-177). California: Sage Publications.

Criado-Jiménez, I., Fernández-Chulián, M., Husillos-Carqués, F. J., \& Larrinaga-González, C. (2008). Compliance with mandatory environmental reporting in financial statements: The case of Spain (2001-2003). Journal of Business Ethics, 79(3), 245-262.

de Villiers, C., \& Alexander, D. (2014). The institutionalisation of corporate social responsibility reporting. British Accounting Review, 46(2), $198-212$.

Dimaggio, P. J., \& Powell, W. W. (1983). The iron cage revisited: Institutional isomorphism and collective rationality in organizational fields. American Sociological Review, 48(2), 147-160.

Doi, T. (1973). The Japanese patterns of communication and the concept of amae. Quarterly Journal of Speech, 59(2), 180-185. 
Doi, T. (1986). The anatomy of self (MA Harbison, Trans). Tokyo: Kodansha International.

EU. (1993). Council Regulation (EEC) No 1836/93 of 29 June 1993. Allowing Voluntary Participation by Companies in the Industrial Sector in a Community Eco-management and Audit Scheme. Official Journal of the European Communities, L168, 36, 1-53.

Fallan, E., \& Fallan, L. (2009). Voluntarism versus regulation: Lessons from public disclosure of environmental performance information in Norwegian companies. Journal of Accounting \& Organizational Change, 5(4), 472-489.

Fifka, M. S., \& Drabble, M. (2012). Focus and standardization of sustainability reporting - A comparative study of the United Kingdom and Finland. Business Strategy and the Environment, 21(7), 455-474.

Freedman, M., \& Jaggi, B. (2005). Global warming, commitment to the kyoto protocol, and accounting disclosures by the largest global public firms from polluting industries. The International Journal of Accounting, 40(3), 215-232.

Frost, G. R. (2007). The introduction of mandatory environmental reporting guidelines: Australian evidence. Abacus, 43(2), 190-216.

GAO. (2004). Environmental disclosure: SEC should explore ways to improve tracking and transparency of information (Report No. GAO04-808). Retrieved from https://www.gao.gov/products/GAO-04-808

Gnanaweera, K. A. K., \& Kunori, N. (2018). Corporate sustainability reporting: Linkage of corporate disclosure information and performance indicators. Cogent Business \& Management, 5(1), 1423872.

Gray, R., Owen, D., \& Adams, C. (2009). Some theories for social accounting?: A review essay and a tentative pedagogic categorisation of theorisations around social accounting. In M. Freedman, \& B. Jaggi (Ed.), Sustainability, environmental performance and disclosures (Advances in environmental accounting \& management, Volume 4) (pp. 1-54). Emerald Group Publishing Limited. 
Haley, J. O. (1991). Authority without power: Law and the Japanese paradox. New York: Oxford University Press.

Higgins, C., \& Larrinaga, C. (2014). Sustainability reporting: Insight from institutional theory. In J. Bebbington, J. Unerman, \& B. O'Dwyer (Ed.), Sustainability Accounting and Accountability ( $2^{\text {nd }}$ ed., pp. 273-285). London: Routledge.

Higgins, C., Milne, M. J., \& van Gramberg, B. (2015). The uptake of sustainability reporting in Australia. Journal of Business Ethics, 129(2), 445-468.

Ho, L. C. J., \& Taylor, M. E. (2007). An empirical analysis of triple bottomline reporting and its determinants: Evidence from the United States and Japan. Journal of International Financial Management \& Accounting, 18(2), 123-150.

Holland, L., \& Foo, Y. B. (2003). Differences in environmental reporting practices in the UK and the US: The legal and regulatory context. The British Accounting Review, 35, 1-18.

ISO. (2017). The ISO Survey of Management System Standard Certifications: ISO 14001- Environmental Management Systems - Requirements with Guidance for Use. Retrieved from https://www.iso.org/the-iso-survey. $\mathrm{html}$

Iwata, K., Arimura, T., \& Takenouchi, H. (2008). Developments in corporate environmental disclosure: Building a database of environmental reports and CSR reports [in Japanese]. Sophia Economic Studies, 53(1), 31-44.

Kagan, R. A. (2000). Introduction: Comparing national styles of regulation in Japan and the United States. Law \& Policy, 22(3 \& 4), 225-244.

Kamath, R. (2010). ESG Practices across Developed Markets: Comparison of Trends across Americas, Europe, and Asia. Retrieved from https:// www.thomsonreuters.com/content/dam/openweb/documents/pdf/trcom-financial/report/esg-practices-across-developed-markets.pdf 
Kawahara, N. (2017). Current trends and challenges in sustainability reporting practices in Japan - Literature review. Journal of Business Studies, 64(2), 113-142.

Kokubu, K., Nashioka, E., Saio, K., \& Imai, S. (2003). Two governmental initiatives on environmental management accounting and corporate practices in Japan. In M. Bennett, P. M. Rikhardsson, \& S. Schaltegger (Eds), Environmental management accounting-Purpose and progress (pp. 89-113). Dordrecht: Springer.

Kokubu, K., Noda, A., Onishi, Y., \& Shinabe, T. (2001). Determinants of environmental report publication in Japanese companies. The Third Asia Pacific Interdisciplinary Research in Accounting Conference in Association with Accounting, Auditing \& Accountability Journal.

Kolk, A. (2005). Environmental reporting by multinationals from the Triad: Convergence or divergence? Management International Review, 45(1), 145-146.

Komura, K. (2009). Consider the spread of sustainability report in Japan. Journal of the Japan Association for Social and Economic System Studies, 30, 89-95.

KPMG. (2002). KPMG International Survey of Corporate Sustainability Reporting 2002.

KPMG. (2005). KPMG International Survey of Corporate Social Responsibility Reporting 2005. Amsterdam.

KPMG. (2008). KPMG International Survey of Corporate Responsibility Reporting 2008. Amsterdam.

KPMG. (2011). International Survey of Corporate Responsibility Reporting 2011.

KPMG. (2013). The KPMG Survey of Corporate Responsibility Reporting 2013. 
KPMG. (2015). Currents of Change: The KPMG Survey of Corporate Responsibility Reporting 2015.

KPMG. (2017). The Road Ahead: The KPMG Survey of Corporate Responsibility Reporting 2017.

Laine, M. (2009). Ensuring legitimacy through rhetorical changes?: A Longitudinal interpretation of the environmental disclosures of a leading Finnish chemical company. Accounting, Auditing \& Accountability Journal, 22(7), 1029-1054.

Lawrence, T., Suddaby, R., \& Leca, B. (2011). Institutional work: Refocusing institutional studies of organization. Journal of Management Inquiry, 20(1), 52-58.

Leca, B., \& Naccache, P. (2006). A critical realist approach to institutional entrepreneurship. Organization, 13(5), 627-651.

Mata, C., Fialho, A., \& Eugénio, T. (2018). A decade of environmental accounting reporting: What we know? Journal of Cleaner Production, 198, 1198-1209.

Meyer, J. W., \& Rowan, B. (1977). Institutionalized organizations: Formal structure as myth and ceremony. American Journal of Sociology, 83(2), $340-363$.

Moll, J., Burns, J., \& Major, M. (2006). Institutional theory. In Z. Hoque (Ed.), Methodological issues in accounting: Theories and methods (pp. 183-205). London: Spiramus.

Orito, Y., \& Murata, K. (2008). Socio-cultural analysis of personal information leakage in Japan. Journal of Information, Communication and Ethics in Society Socio-Cultural, 6(2), 161-171.

Porter, T., \& Ronit, K. (2006). Self-regulation as policy process: The multiple and criss-crossing stages of private rule-making. Policy Sciences, 39(1), $41-72$. 
Saka, C., \& Burritt, R. (2003). Environmental accounting in Japan Recent evidence. Journal of the Asia Pacific Centre for Environmental Accountability, 9(4), 4-10.

Sato, E., Matsuda, K., \& Carducci, B. J. (2018). A factor analytical investigation of the Japanese translation of the Cheek-Buss Shyness Scale in support of the three-component model of shyness. Personality and Individual Differences, 124, 160-167.

Schaede, U. (1999). Self-Regulation and the Sanctuary Strategy: Competitive Advantage through Domestic Cooperation by Japanese Firms. Retrieved from https://academiccommons.columbia.edu/ doi/10.791 6/D82Z1D2J.

Schrader, A. (2019). Sustainability reporting across Asia: Trends and challenges. Retrieved from https://www.conference-board.org/blog/ sustainability/Asia-Sustainability-Reporting-Trends

Scott, W. R. (1995). Institutions and organizations (Foundations for organizational science). London: Sage Publication.

Smith, J., Adhikari, A., \& Tondkar, R. H. (2005). Exploring differences in social disclosures internationally: A stakeholder perspective. Journal of Accounting and Public Policy, 24(2), 123-151.

Thornton, P. H., Ocasio, W., \& Lounsbury, M. (2015). The institutional logics perspective. In R. Scott, \& S. Kosslyn (Ed.), Emerging trends in the social and behavioral sciences: An interdisciplinary, searchable, and linkable resource (pp. 1-22). Hoboken, NJ: John Wiley \& Sons, Inc.

Volden, C., \& Wiseman, A. E. (2012). Governmental Regulation and SelfRegulation. Retrieved from http://www.vanderbilt.edu/csdi/events/ prvtgov_wiseman.pdf

Wagatsuma, H., \& Rosett, A. (1983). Cultural attitudes towards contract law: Japan and the United States compared. UCLA Pacific Basin Law Journal, 2(1-2), 76-96. 
Wanderley, L. S. O., Lucian, R., Farache, F., \& De Sousa Filho, J. M. (2008). CSR information disclosure on the web: A context-based approach analysing the influence of country of origin and industry sector. Journal of Business Ethics, 82(2), 369-378.

WBCSD. (2019). Corporate and Sustainability Reporting Trends in Japan. Retrieved from https://www.wbcsd.org/Programs/Redefining-Value/ External-Disclosure/The-Reporting-Exchange/Resources/Corp orateand-sustainability-reporting-trends-in-Japan

Yamagami, T., \& Kokubu, K. (1991). A note on corporate social disclosure in Japan. Accounting, Auditing \& Accountability Journal, 4(4), 32-39.

Yamagami, T., \& Tomimasu, K. (1993). The Japanese Valdez society and environmental auditing research group. Social and Environmental Accountability Journal, 13(1), 16-16.

Yook, K.-H., Song, H., Patten, D. M., \& Kim, I.-W. (2017). The disclosure of environmental conservation costs and its relation to eco-efficiency: Evidence from Japan. Sustainability Accounting, Management and Policy Journal, 8(1), 22-24. 